\title{
The Analysis of Distributed Two-Layers Components in Three-Layer Planar Structure
}

\author{
Rassokhina Yu. V., Krizhanovski V. G. \\ Vasyl' Stus Donetsk National University \\ E-mail:wgd888@gmail.com
}

\begin{abstract}
The algorithms for analyzing of two-layer distributed discontinuities in the form of an inductive section in a microstrip transmission line and an H-shaped slot resonator with a transverse arrangement of "dumbbells" in its ground plane by the transverse resonance method are improved and developed. This method includes the mutual coupling of components that make up the discontinuity. According to the analysis results, the considered discontinuity is a multifunctional device and has scattering characteristics that contain simultaneously signal transmission and rejection. At this the two-layer discontinuity provides a wideband (up to $40 \%$ ) rejection with two-frequency characteristic of resonant reflection, and forms either two narrowband passband filters (about $3 \%$ ), or one wideband (up to $10 \%$ ) passband.
\end{abstract}

Key words: microstrip line; inductive section; H-shaped slot resonator; eigen frequency spectrum; scattering characteristics

\section{Introduction}

The spectral approach for solution of boundary problems in micro- and millimeter wave range devices design was developed since 80-th years of last century [1]. The analysis of multilayer planar structures in spectral domain allows define boundary problem in the form of integral equation, which boils down to solution of lower order linear equation system, and provides calculation of structural components in passive devices being designed. The transverse resonance technique is also based at the spectral approach, in which eigen frequencies of virtual resonators with boundary conditions in the form of electric or magnetic walls are used for scattering characteristics calculation.

In [2], the resonance frequencies technique calculation for multilayer planar structure consisted of microstripline resonator at coupled lines and tunable slot resonator in second plane is described. This technique is based on field description of shielded structure in spectral domain in the form of hybrid waves and boundary problem solution by Galerkin's method. The Green's functions formulated for the area being analyzed are universal and applied to various microstripstrip-slot structures. The generalized analysis and design technique for multilayer components based on combination of spectral approach (using immittance matrix) and standard methods of CAD is described in [3-6]. The interest of researchers in multi-layer planar structures, including DGS-structures (defected ground structure), does not weaken, on their basis, differential bandpass fi- lters, directional coupler and vertical transitions are designed [7-15].

In the paper [16], the scattering characteristics of fundamental wave in microstrip line at $\mathrm{H}$-shaped slot resonators with various orientation relative to microstrip line were considered. It was shown, that the such discontinuities provide two-frequency, particularly, wideband attenuation, caused by the discontinues interaction at relatively big distances from each other. The scattering characteristics of multilayer distributed discontinuities included step discontinuity in microstrip line (inductive or capacitive sections) and narrow rectangular slot resonators were considered in works $[17,18]$.

The aim of this work is improving the design technique and investigation of the scattering characteristics singularities at a two-layer distributed discontinuity in three-layer planar structure consisted the inductive microstrip section and $\mathrm{H}$-shaped slot resonator with transversal arrangement of the "dumbbells" in ground plane. The potentially advantages of such structures are extended device functionality and compactness compared with conventional slot resonator [19].

\section{Solution of boundary problem for resonator with symmetrical discontinuity}

Calculation of scattering matrix elements (reflection and transmission coefficients) by transverse resonance technique is performed by using solution 
of boundary eigenfrequencies problems for a half-wave resonator in main transmission line, which contains the investigated discontinuity with nodes and antinodes at virtual boundaries. Because of this, it is of interest to investigate the eigenfrequencies spectra of such a resonator. The procedure of boundary problems solution for resonator with discontinuities in microstrip line and ground plane is described in detail in [17]. The algebraization of boundary problems is carried out using the waveguide basis functions $T_{h(e) y, k}, \quad k=1 . . N_{s}$, by which the field at aperture of complex shape slot resonator is decomposed, and using vector potentials (electric and magnetic) for the current density in nonhomogenous strip line $J_{e(h), n}(x, z), k=1 . . N_{w}$ [17]. As in [17], the trigonometric basis is used to describe currents densities in nonuniform strip resonator, on the basis which the two-dimensional eigen functions $J_{e(h), n}(x, z)$ are built, which satisfy the Helmholtz equation and corresponding boundary conditions at free ends of strip line and resonator:

$$
\Delta_{\perp} J_{e(h), n}(x, z)+\chi_{e(h), n}^{2} \cdot J_{e(h), n}(x, z)=0,
$$

where $\chi_{e(h), n}^{2}$ - are eigen values of the electric and magnetic potentials describing current density in nonhomogeneous strip line.

The resonator with width step in microstrip transmission line is shown in Fig. 1a. As noticed in [17], the calculation of the eigen value $\chi_{e, n}^{2}$ of electric and magnetic potentials for the current density $J_{e, n}(x, z)$, which are greater in order than the eigen numbers $\chi_{h, n}^{2}$ for the current density $J_{h, n}(x, z)$, takes a significant time. Let's estimate the contribution of these functions to values of the slot resonator eigen frequencies $f_{\text {res }}$. In Fig. 1b it is shown the typical dependence of the first two eigen values $\chi_{h, n}$ of magnetic potential for the current density $J_{h, n}(x, z)$ on the distance to boundary $l_{2}$ obtained by solving the two-dimensional problems, and the results of eigen frequencies $f_{\text {res }}$ calculation for microstrip resonator with inductive section taking and not taking into account the current density components described by the electric potential $J_{e, n}(x, z)$ are shown in Fig. 1c. It follows from the numeric calculation that contribution of the $J_{e, n}(x, z)$ component to resonant frequency value contains about 0.05-0.07 GHz, which corresponds to $2 \%$ regarding central frequency of bandwidth. Because of this, it is enough to consider only magnetic vector potential to optimize calculation time of one frequency point for current density characterization. If more precision is required, for example, analysis of final device topology, one can add the $J_{e, n}(x, z)$ component to the algorithm. The distributed two-layer symmetrical discontinuity in three-layer planar structure is shown in Fig. 2. According to the transverse resonance technique, the scattering matrix elements for symmetrical discontinuity are calculated by solving boundary problems for resonator with boundary conditions in form of electric wall (e.w.-e.w. conditions) and magnetic wall (m.w.- m.w. conditions) for resonator regarding dimension $l_{2, i}$ (see Fig. 2, the discontinuity dimension $l_{1}$ is not changed considering the reference plane) by the equations [17]:

$$
S_{11}=\frac{\Gamma_{2}-\Gamma_{1}}{2}, \quad S_{12}=\frac{\Gamma_{1}+\Gamma_{2}}{2}
$$

where $\Gamma_{i}=\exp \left(2 j \cdot \beta_{z} l_{2, i}\right)$, indexes $i=1,2$ corresponds to solution of "electric" and "magnetic" boundary problems correspondingly, $\beta_{z}$ - propagation constant of fundamental wave in regular microstrip transmission line.

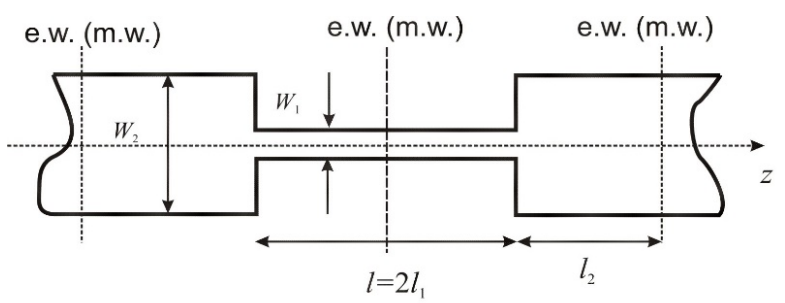

(a)

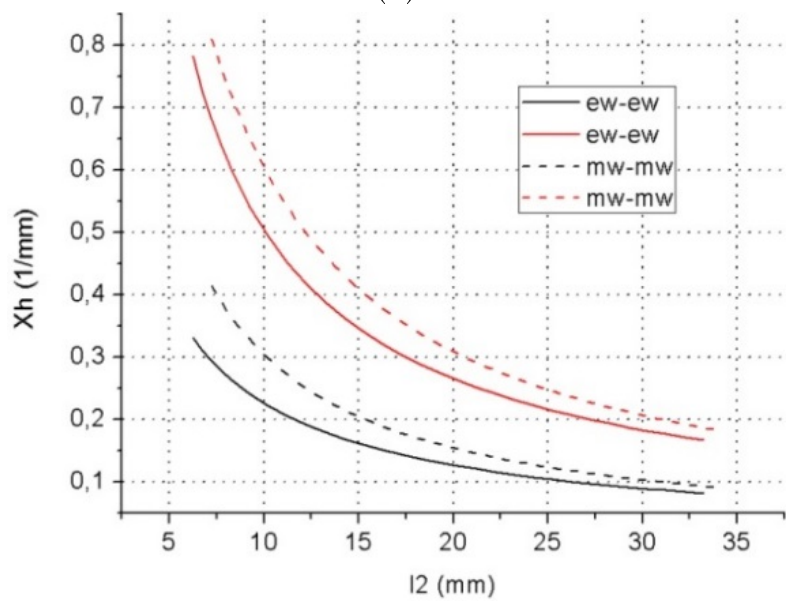

(b)

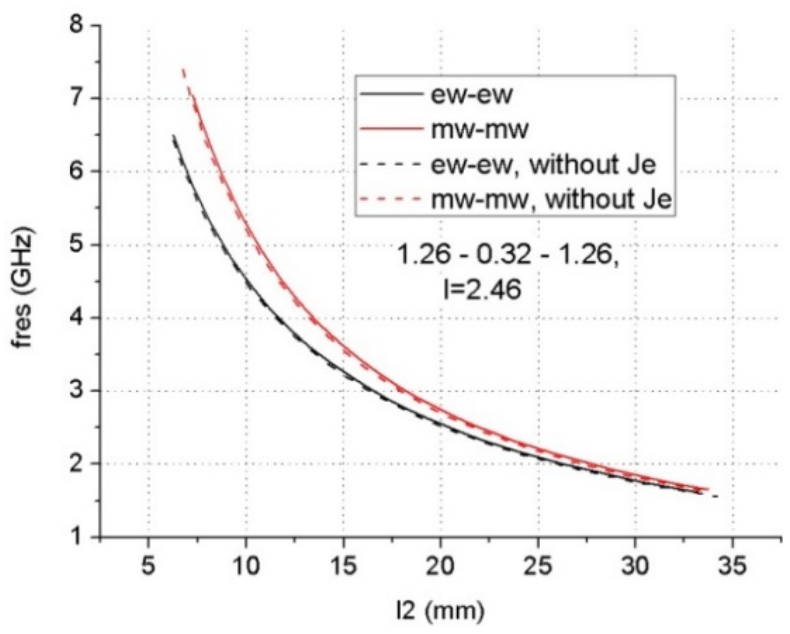

(c)

Fig. 1. (a) Boundary conditions for microstrip resonator with inductive section, (b) solution of problem on magnetic potential eigenvalues for current density, and (c) solutions of boundary problems on resonator eigenfrequencies with electric and magnetic walls at longitudial boundaries. 


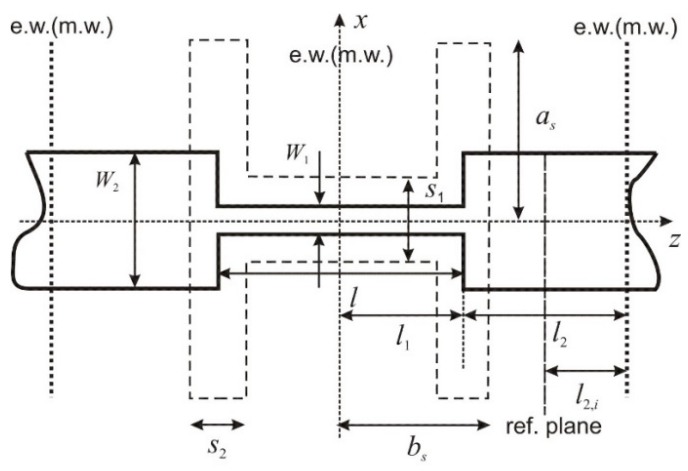

(a)

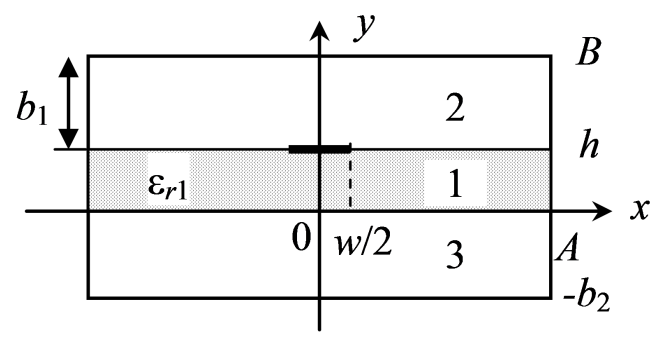

(b)

Fig. 2. The three-layer structure with symmetrical two-layer distributed discontinuity in microstrip transmission line, consisted of inductive strip line section and $\mathrm{H}$-shaped slot resonator in ground plane with transversal arrangement of the "dumbbells".

The terms "electric" and "magnetic" correspond to boundary conditions at longitudinal boundaries of resonator (along the $z$ axis). According to (1), the minimum of the reflection coefficient is defined by intersection of the spectral curves obtained by solving the both boundary problems, i.e. at the frequencies on which $\Gamma_{1}=\Gamma_{2}$ the minimum of $\left|S_{11}\right|=\left|S_{22}\right|$ is observed.

Similarly, the scattering matrix elements of symmetrical discontinuity are calculated also by solving the boundary problems of the form e.w.-e.w. and m.w.-e.w. for the resonator regarding it's longitudinal dimension $l_{2, i}$ (Fig. 2) by the equations [18]:

$$
S_{11}=-\frac{\Gamma_{1}+\Gamma_{2}}{2}, \quad S_{12}=\frac{\Gamma_{1}-\Gamma_{2}}{2} .
$$

The intersection points of spectral curves $\Gamma_{1}=$ $\Gamma_{2}$ define resonant interaction frequencies of the fundamental wave in microstrip line with discontinuity, at which the transmission coefficient $\left|S_{12}\right|=\left|S_{21}\right|$ equals to zero.

\section{Analysis result of two-layer di- scontinuity}

The calculations were fulfilled reducing the number of basis functions to 300 terms of series, trigonometric basis for current density to 10-12 terms of series, 3-4 eigenfunctions of magnetic type for current density in microstrip line $N_{w}$, and 2-3 H- and E-type waveguide functions in field description at the slot resonator aperture. Here and below the substrate thickness is $h=0.365 \mathrm{~mm}$, dielectric permittivity is $\varepsilon_{r 1}=10.2$, three-layer shield dimensions (in $\mathrm{mm}$ ) are: $A=15.0$, $B=7.365, b_{2}=5.0$ (Fig. 2). The investigation of the calculation algorithm showed that the solution is most sensitive to number of considered eigen waves in microstrip line (Fig. 3). The difference in the values of the resonant frequencies is most noticeable on the sections of the curves, which are not used for calculation of the scattering matrix elements.
The eigen frequencies spectrum of the resonator with two-layer distributed discontinuity obtained solving the three boundary problems and corresponding scattering characteristics are shown in Fig. 4. The structure dimensions for calculation the eigen frequencies spectrum are: $w_{1}=0.3 \mathrm{~mm}, w_{2}=1.2 \mathrm{~mm}$, length of inductive section $l=2 l_{1}=1.8 \mathrm{~mm}\left(l_{1}=\right.$ $0.9 \mathrm{~mm}$ ). The parameters of slot resonator (in $\mathrm{mm}$ ) are: $a_{s}=8.7, b_{s}=5.2, s_{1}=0.3, s_{2}=0.6$.

It can be seen from the figure that the eigen frequencies spectrum of resonator with distributed discontinuity consists of a minimum of two branches. The lower branch (for all boundary problems) corresponds to strip mode of resonator, and all upper - waveguide modes. Their interception corresponds to frequencies of resonant interaction of feeding transmission line with discontinuities in it. At that, the spectrum of eigen frequencies of resonator with electric walls has the same form as the spectrum of electromagnetically coupled discontinuities [16].

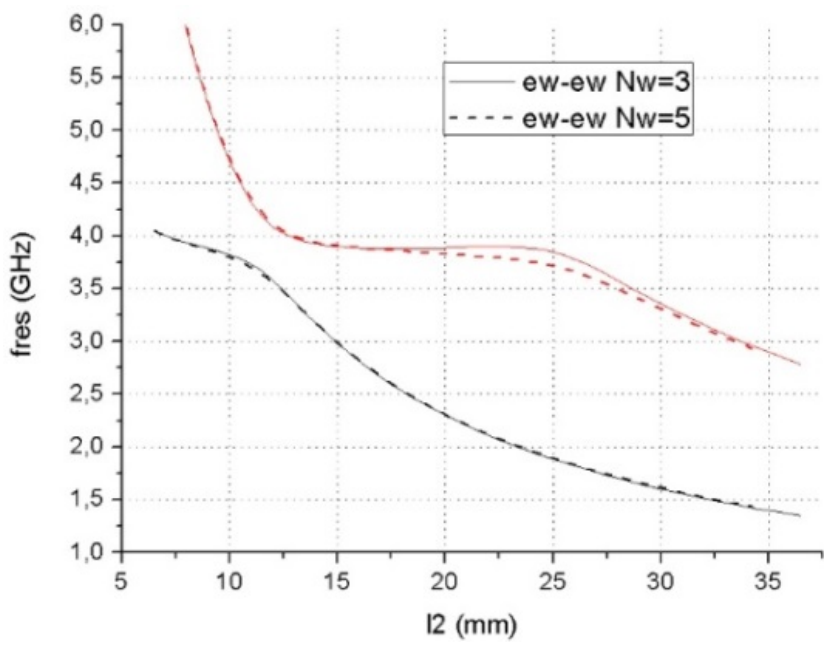

Fig. 3. Eigen frequencies spectra for microstrip resonator with distributed discontinuity obtained by solution of the "electric" boundary problem depending on the number of considered eigenfunctions for current density in non-homogeneous strip line. 


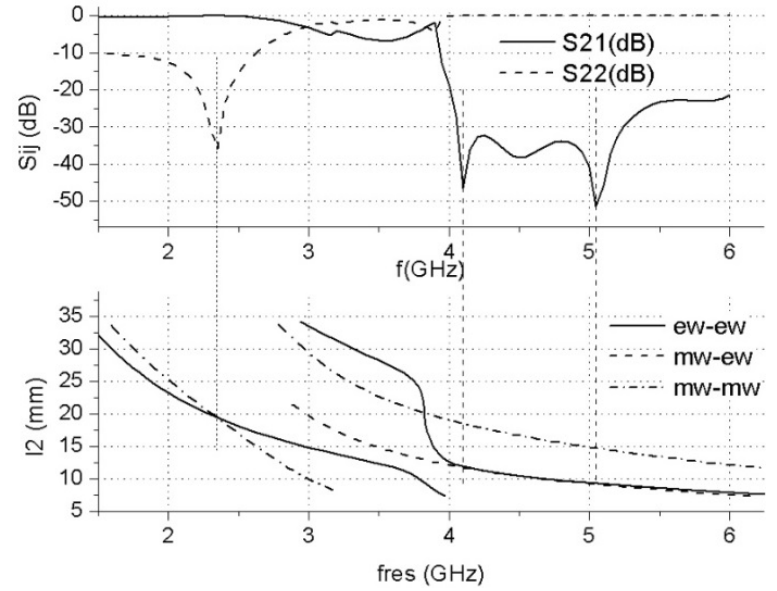

(a)

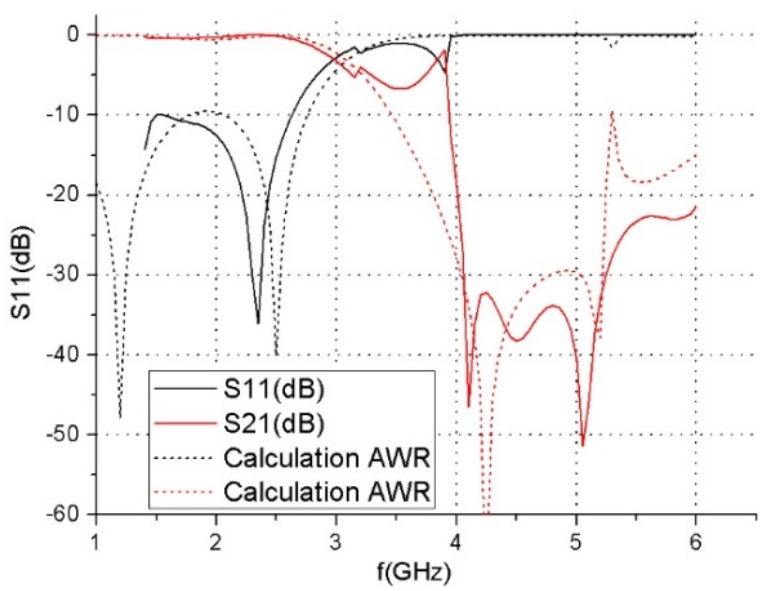

(b)

Fig. 4. Eigen frequencies spectrum of microstrip resonator with distributed discontinuity obtained solving the three boundary problems: "electric", "magnetic", and "magneto-electric" and corresponding scattering characteristics. The structure dimensions are: $w_{1}=0.3 \mathrm{~mm}, w_{2}=1.2 \mathrm{~mm}$, length of inductive section $l=2 l_{1}=1.8 \mathrm{~mm}$

$\left(l_{1}=0.9 \mathrm{~mm}\right)$. The parameters of slot resonator are: $a_{s}=8.7 \mathrm{~mm}, b_{s}=5.2 \mathrm{~mm}, s_{1}=0.3 \mathrm{~mm}, s_{2}=0.6$

Likewise [17], the type of spectral curves allows approximate them by rational functions in the form $f(x)=1 / Q_{m}(x)$, where $Q_{m}(x)=a_{0}+a_{1} x+$ $a_{2} x^{2}+\ldots+a_{m} x^{m}-$ is a polynomial of order $\mathrm{m}$, and only the corresponded to waveguide solution curve branch is used to approximate the solution of "electric" boundary problem. The approximation of spectral functions allows significantly decrease calculation time of the scattering matrix elements for one frequency point. For example, the calculation time of both spectrum branches in the wavelength range $5-35 \mathrm{~mm}$ (approximately frequency band 1.5-7.0 $\mathrm{GHz}$ ) takes about $60 \mathrm{~min}$ at the average, whereas the solution of inverse problem (calculation of resonator length at given frequency) takes about 8 hours (at the PC Intel@ Core $^{T M} \mathrm{i} 3-330 \mathrm{M} @ 2.13 \mathrm{GHz}$ ). The scattering characteristics of discontinuity calculated using the spectral curves approximation of the form $f(x)=$ $1 / Q_{m}(x)$ and calculated using commercial microwave simulation software are shown in Fig. 4b. The difference in analysis results is caused by considering the boundary conditions at ideal metal walls in ports plane in commercial software and using there the net methods for electromagnetic fields calculation. It is seen that the considered discontinuity provides passing with bandwidth about $12 \%$ with central frequency $2.35 \mathrm{GHz}$ and wideband attenuation in the bandwidth 4-6 GHz. For comparison, a single discontinuity in the form of inductive section does not have resonant frequencies of reflection coefficient at the considered frequency band, but in combination with a complex shape slot resonator makes a structure, which characteristics have frequencies of resonant reflection and passing simultaneously in the band 1-6 GHz.

The comparative spectrum curves and their approximation by rational functions are shown in Fig. 5. As it is shown in Fig. 5a, only the high-frequency branch of second curve (from 4 to $6 \mathrm{GHz}$ ) is used to approximate eigenfrequencies spectrum obtained by solving of the "electric" problem, excepting lower branch.

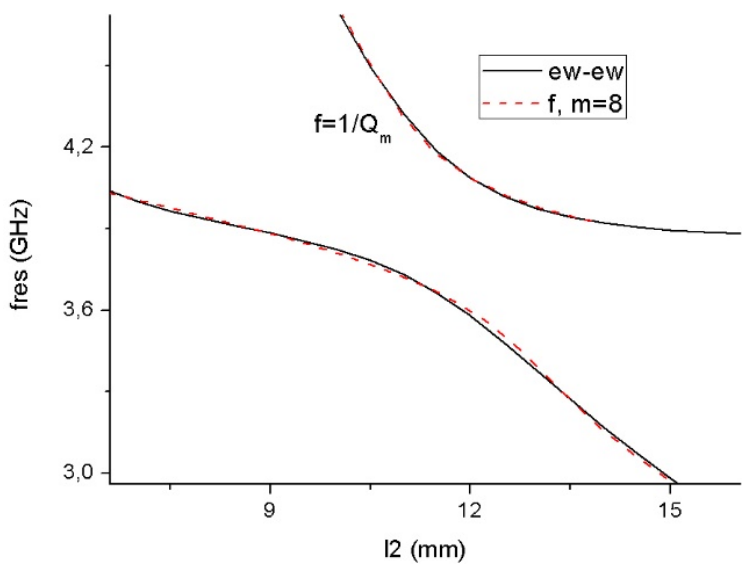

(a)

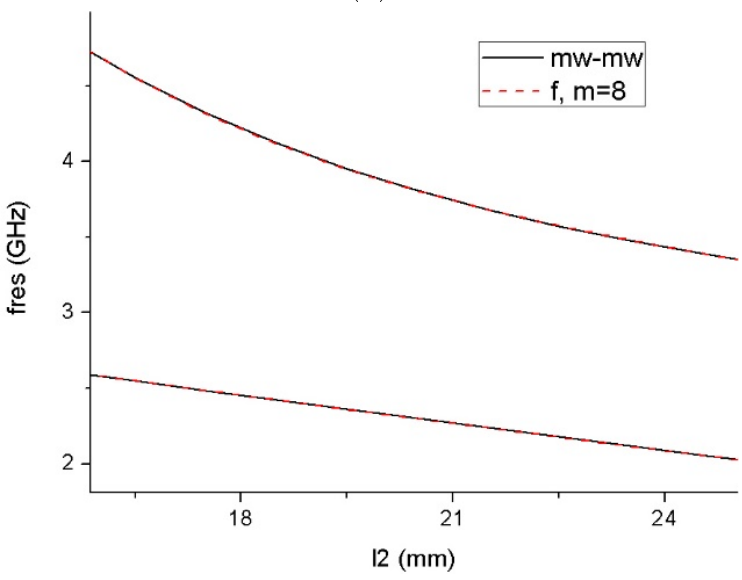

(b)

Fig. 5. Approximation of eigen frequencies spectra for slot resonator with discontinuity using rational functions of the form $f(x)=$ $1 / a_{0}+a_{1} x+a_{2} x^{2}+\ldots+a_{m} x^{m}$. 
To approximate solution of the "magnetic" boundary problem the both whole branches are used, Fig. 5b. Here and below high order polynomials $(m=$ 8..10) were used for the scattering matrix calculation depending on type of the spectral characteristic. All the above described algorithms were realized using Delphi 7.0 software.

The similar characteristics were obtained for the distributed discontinuity with greater length of inductive section and H-shaped slot resonator, Fig. 6. The Sshaped parts in eigen frequencies spectral curves for resonator with discontinuity are typical for lengthy discontinuities (when longitudinal dimension $2 b_{s}$ is of the order of $\lambda / 4)$. The scattering characteristics of the discontinuity with such a topology contain two frequencies of resonant reflection and one frequency of resonant passing. The pass band by the level $-15 \mathrm{~dB}$ contains $10 \%$, and the stop band about $35 \%$.

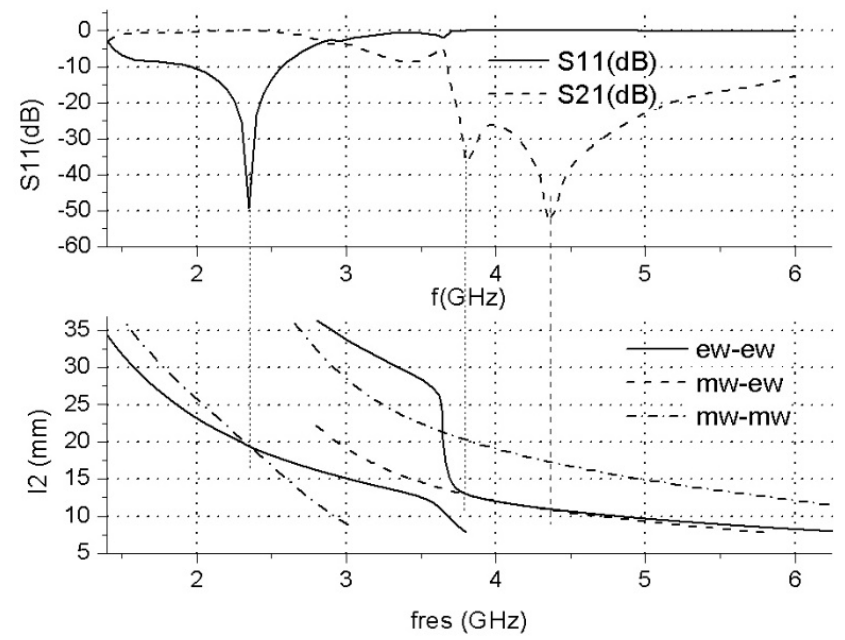

Fig. 6. Spectra of eigen frequencies for resonator with distributed two-layer discontinuity obtained by solving the three boundary problems: "electric", "magnetic", and "magneto-electric" and corresponding scattering characteristics. The parameters of discontinuity are $w_{1}=0.3 \mathrm{~mm}, w_{2}=1.2 \mathrm{~mm}$, length of inductive section $l=2.4 \mathrm{~mm}\left(l_{1}=1.2 \mathrm{~mm}\right)$, the parameters of slot resonator (in $\mathrm{mm}$ ) are $a_{s}=9.6, b_{s}=6.0, s_{1}=0.9$,

$$
s_{2}=0.6 \text {. }
$$

To demonstrate interaction of the discontinuities in two layers the curves of eigen frequencies spectra for each taken separately discontinuity are shown below. The corresponding curves obtained by solving the boundary problems for inductive section in strip line and $\mathrm{H}$-shaped slot resonator are shown in Fig. 7a,b. It is seen that each taken discontinuity has different eigen frequencies curves, and correspondingly, scattering characteristics. And at that, the transmission characteristic does not have points of resonant signal reflection at all (only a certain minimum), and the reflection characteristic has one resonance at the frequency $4.35 \mathrm{GHz}$.

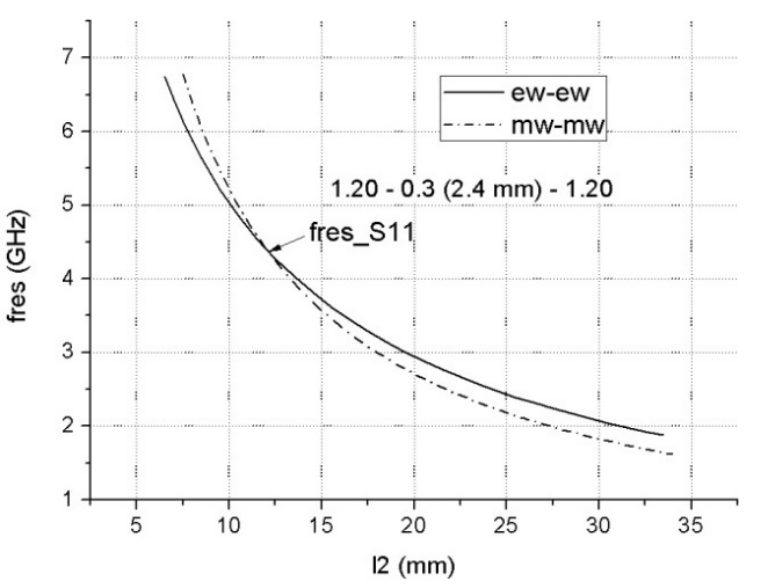

(a)

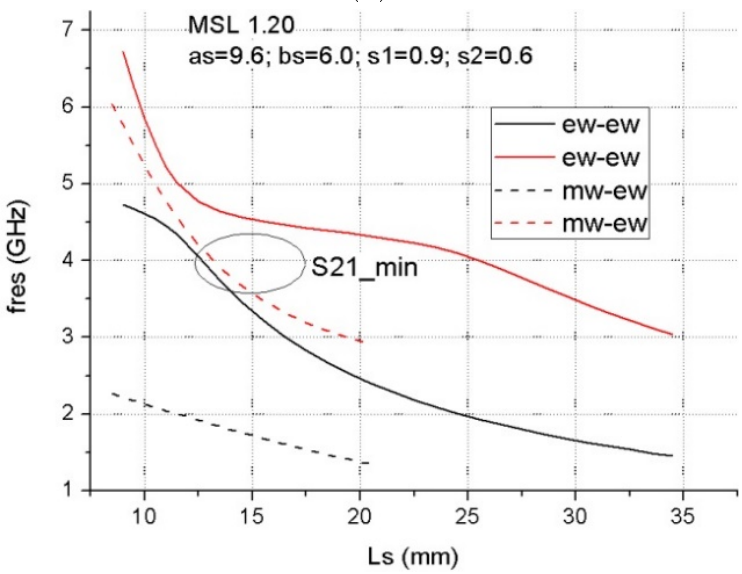

(b)

Fig. 7. Spectra of eigen frequencies with separated distributed discontinuities in the form of inductive section in microstrip line and $\mathrm{H}$-shaped slot resonator

(parameters of the structure are given in Fig. 6).

The spectra of the eigen frequencies and the characteristics of the two-layer distributed discontinuity with passband (9.6\%) and wide stopband are shown in Fig. 8. It is seen that such characteristics can be obtained, if spectral curves obtained by solving the "electric" and the "magnetic" boundary problems have only one intersection point (intersection of two branches of strip modes), and curves of higher waveguide modes obtained by solving the "electric" and "magneto-electric" problems intersect at least in two points (Fig. 8).

In the two-frequency version of discontinuity topology the stop band is placed between two frequencies of resonant passing, Fig. 9a,b. The stop band contains $16 \%$ by the level $-20 \mathrm{~dB}$ and has larger slope. Besides, this structure passes signal in two narrow (about 3\%) bands with resonant minimums at the frequencies $2.45 \mathrm{GHz}$ and $4.25 \mathrm{GHz}$. In the spectral curves graphs, it is expressed in the form of interception points of either of the two (strip and waveguide) curves obtained by solving electric and magnetic boundary problems, as well as in the form of narrow interception region of the first (strip) branch corresponded to electric problem solution and the second (wavegui- 
de) branch corresponded to magneto-electric problem solution.

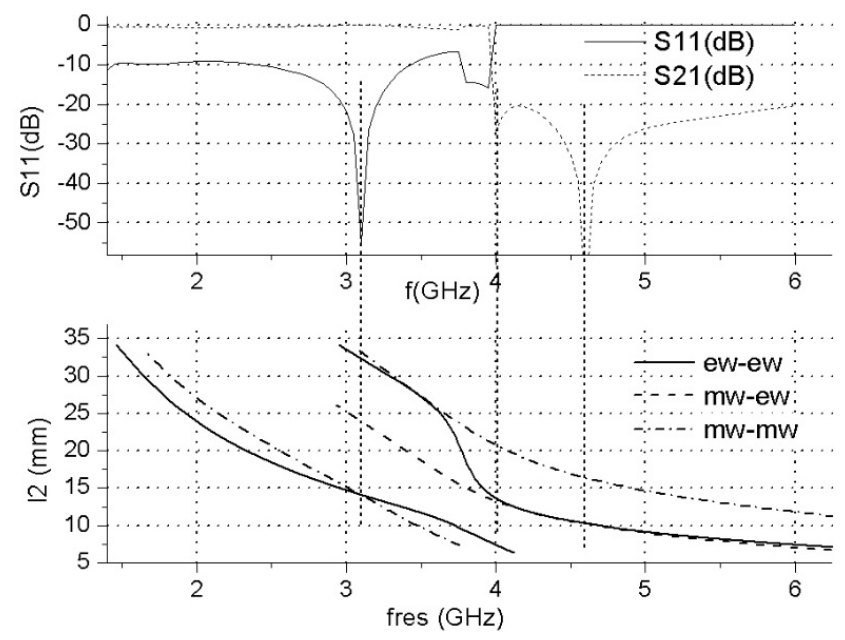

Fig. 8. Spectra of eigen frequencies for resonator with distributed two-layer discontinuity obtained by solving the three boundary problems and corresponding scattering characteristics. The parameters of discontinuity are $w_{1}=0.3 \mathrm{~mm}, w_{2}=1.0 \mathrm{~mm}$, length of inductive section $l=2.4 \mathrm{~mm}\left(l_{1}=1.2 \mathrm{~mm}\right)$, the parameters of slot resonator (in $\mathrm{mm}$ ) are $a_{s}=7.6, b_{s}=4.6, s_{1}=0.6$, $s_{2}=0.4$.

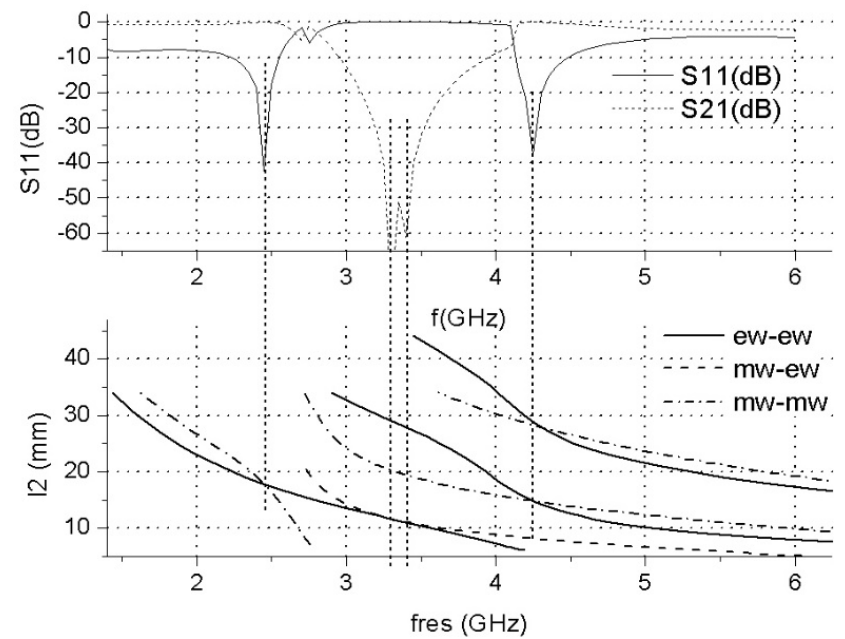

Fig. 9. Spectra of eigen frequencies for resonator with distributed two-layer discontinuity obtained by solving the three boundary problems and corresponding scattering characteristics. The parameters of discontinuity are $w_{1}=0.3 \mathrm{~mm}, w_{2}=0.9$, length of inductive section $l=1.8 \mathrm{~mm}\left(l_{1}=0.9 \mathrm{~mm}\right)$, the parameters of slot resonator (in $\mathrm{mm}$ ) are $a_{s}=12.0, b_{s}=4.0, s_{1}=0.6$,

$$
s_{2}=0.4 \text {. }
$$

To compare spectra and demonstrate interaction of the elements, which contains two-layer discontinuity, the spectra of eigen frequencies for resonators contained inductive strip line section and H-shaped slot resonator are shown in Fig. 10a,b. In this case the inductive microstrip line section does not have resonant passing frequencies at all in the considered frequency band 1-6 GHz, and slot resonator rejects signal in wide frequency band with the resonant reflection frequencies about $3.0 \mathrm{GHz}$ and $4.5 \mathrm{GHz}$.

Note that the developed algorithms allow analyze more complex structures and design wideband junctions and filters, for example, considered in [19]. Unlike [19], the above considered structures perform at least the two functions: passing and stopping in different microwave sub-bands.

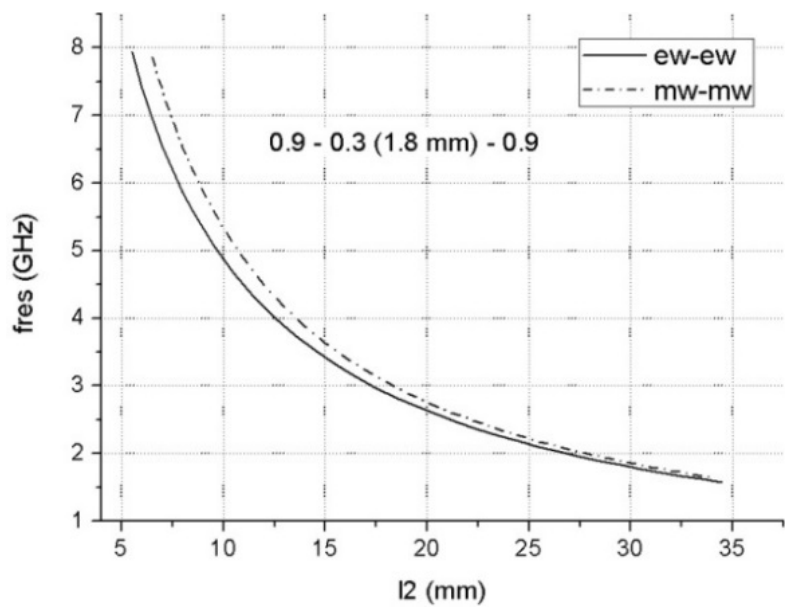

(a)

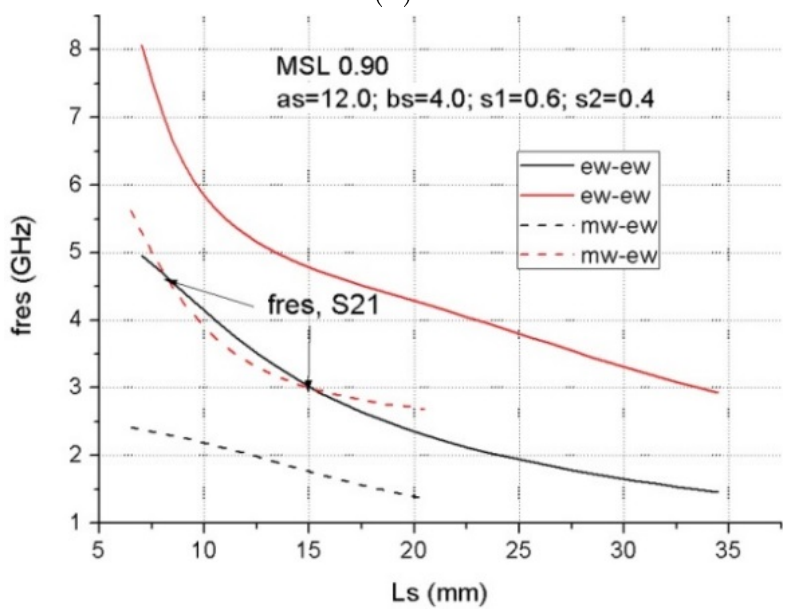

(b)

Fig. 10. Spectra of eigen frequencies with separated distributed discontinuities in the form of inductive strip line section and $\mathrm{H}$-shaped slot resonator (parameters of the structure are the same as in Fig. 9).

\section{Conclusion}

The technique of boundary problems solution for resonators based on a three-dimensional planar structure with discontinuity, which components are placed in two planes simultaneously and contain the width step in microstrip line and slot resonator of complex shape in ground plane, was improved. It has been demonstrated that current density in nonhomogeneous strip line is well described (2\% error for eigen frequencies spectrum calculation) by the magnetic vector potential function, which is expressed as decomposition on a trigonometric basis. The 
transverse resonance technique used to calculate the scattering characteristics from the data of calculation of the eigen frequencies spectra was realized by means of spectral curves approximation using the functions in form $f(x)=1 /\left(a_{0}+a_{1} x+a_{2} x^{2}+\ldots+a_{m} x^{m}\right)$. Because of this algorithm optimization, the calculation time of discontinuity analysis is significantly reduced.

The algorithms of boundary problems for resonators with discontinuity in the form of microstrip inductive section and $\mathrm{H}$-shaped slot resonator in ground plane with transverse placement of the "dumbbells" were developed. The analysis revealed that the considered discontinuity possesses the scattering characteristics having both pass bands and stop bands simultaneously, i.e. it serves a multifunctional device. Their width and mutual placement relative to each other are selected by varying of the multilayer discontinuity dimensions considering it's composing elements interaction. At this the two-layer discontinuity provides a wideband (up to $40 \%$ ) rejection with two-frequency characteristic of resonant reflection, and forms either two narrowband passband filters (about $3 \%$ ), or one wideband (up to $10 \%$ ) passband.

\section{References}

[1] Jansen R. (1985) The Spectral-Domain Approach for Microwave Integrated Circuits. IEEE Transactions on $\mathrm{Mi}$ crowave Theory and Techniques, Vol. 33, Iss. 10, pp. 1043-1056. DOI: $10.1109 / \mathrm{tmtt} .1985 .1133168$

[2] Kawano K. (1985) Hybrid-Mode Analysis of Coupled Microstrip-Slot Resonators. IEEE Transactions on Microwave Theory and Techniques, Vol. 33, Iss. 1, pp. 38-43. DOI: $10.1109 /$ tmtt.1985.1132935

[3] Schwab W. and Menzel W. (1992) On the design of planar microwave components using multilayer structures. IEEE Transactions on Microwave Theory and Techniques, Vol. 40, Iss. 1, pp. 67-72. DOI: $10.1109 / 22.108324$

[4] Itoh T. and Hebert A. (1978) A Generalized Spectral Domain Analysis for Coupled Suspended Microstriplines with Tuning Septums. IEEE Transactions on Microwave Theory and Techniques, Vol. 26, Iss. 10, pp. 820. DOI: $10.1109 /$ tmtt.1978.1129493

[5] Itoh T. (1980) Spectral Domain Immitance Approach for Dispersion Characteristics of Generalized Printed Transmission Lines. IEEE Transactions on Microwave Theory and Techniques, Vol. 28, Iss. 7, pp. 733. DOI: $10.1109 /$ tmtt.1980.1130158

[6] Fukuoka Y., Zhang Q., Neikirk D. and Itoh T. (1985) Analysis of Multilayer Interconnection Lines for a HighSpeed Digital Integrated Circuit. IEEE Transactions on Microwave Theory and Techniques, Vol. 33, Iss. 6, pp. 527. DOI: $10.1109 / \mathrm{tmtt} .1985 .1133109$

[7] Kim J.P. and Park W.S. (2002) Novel configurations of planar multilayer magic-T using microstripslotline transitions. IEEE Transactions on Microwave Theory and Techniques, Vol. 50, Iss. 7, pp. 1683. DOI: $10.1109 /$ tmtt.2002.800387

[8] Wang C. and Lin T.H. (2011) A multi-band meandered slotted-ground-plane resonator and its application of lowpass filter. Progress In Electromagnetics Research, Vol. 120, pp. 249-262. DOI: $10.2528 /$ pier 11072203
[9] Guo X., Zhu L., Tam K. and Wu W. (2015) Wideband Differential Bandpass Filters on Multimode Slotline Resonator With Intrinsic Common-Mode Rejection. IEEE Transactions on Microwave Theory and Techniques, Vol. 63, Iss. 5, pp. 1587. DOI: 10.1109/tmtt.2015.2412111

[10] Guo X., Zhu L., Wang J. and Wu W. (2015) Wideband Microstrip-to-Microstrip Vertical Transitions Via Multiresonant Modes in a Slotline Resonator. IEEE Transactions on Microwave Theory and Techniques, Vol. 63, Iss. 6, pp. 1902. DOI: $10.1109 /$ tmtt.2015.2422695

[11] Guo X., Zhu L. and Wu W. (2016) Strip-Loaded Slotline Resonators for Differential Wideband Bandpass Filters With Intrinsic Common-Mode Rejection. IEEE Transactions on Microwave Theory and Techniques, pp. 1. DOI: $10.1109 / \mathrm{tmtt} .2015 .2509065$

[12] Guo X., Zhu L. and Wu W. (2016) Balanced Wideband/Dual-Band BPFs on a Hybrid Multimode Resonator With Intrinsic Common-Mode Rejection. IEEE Transactions on Microwave Theory and Techniques, Vol. 64, Iss. 7, pp. 1997. DOI: 10.1109/tmtt.2016.2569518

[13] Zhang Y., Shi S., Martin R.D. and Prather D.W. (2017) Slot-Coupled Directional Filters in Multilayer LCP Substrates at $95 \mathrm{GHz}$. IEEE Transactions on Microwave Theory and Techniques, Vol. 65, Iss. 2, pp. 476. DOI: $10.1109 / \mathrm{tmtt} .2016 .2615929$

[14] Ting H., Hsu S. and Wu T. (2017) A Novel and Compact Eight-Port Forward-Wave Directional Coupler With Arbitrary Coupling Level Design Using Four-Mode Control Technology. IEEE Transactions on Microwave Theory and Techniques, Vol. 65, Iss. 2, pp. 467. DOI: $10.1109 / \mathrm{tmtt} .2016 .2623709$

[15] Bukuru D., Song K., Zhang F., Zhu Y. and Fan M. (2017) Compact Quad-Band Bandpass Filter Using QuadMode Stepped Impedance Resonator and Multiple Coupling Circuits. IEEE Transactions on Microwave Theory and Techniques, Vol. 65, Iss. 3, pp. 783-791. DOI: $10.1109 / \mathrm{tmtt} .2016 .2638814$

[16] Rassokhina Y.V. and Krizhanovski V.G. (2012) Analysis of coupled slot resonators of complex shape in metalization plane of a micro-strip transmission line using the transversal resonance techniques. Radioelectronics and Communications Systems, Vol. 55, Iss. 5, pp. 214-222. DOI: $10.3103 / \mathrm{s} 0735272712050032$

[17] Rassokhina J.V. and Krizhanovskii V.G. (2017) A method for analyzing irregularities in stripline-slot structures. Part 1: Analysis of a width jump in a microstrip line by the transverse resonance method. Telecommunications and Radio Engineering, Vol. 76, Iss. 8, pp. 653-665. DOI: 10.1615/telecomradeng.v76.i8.10

[18] Rassokhina Yu.V. and Krizhanovskii V.G. (2017) A method for analyzing irregularities in stripline-slot structures. Part 2: Analysis of complex irregularities in three-layer planar structures. Telecommunications and Radio Engineering, Vol. 76, Iss. 12, pp. 1049-1056. DOI: 10.1615/telecomradeng.v76.i12.20

[19] Yang L., Zhu L., Choi W. and Tam K. (2017) Analysis and Design of Wideband Microstrip-to-Microstrip Equal Ripple Vertical Transitions and Their Application to Bandpass Filters. IEEE Transactions on Microwave Theory and Techniques, Vol. 65, Iss. 8, pp. 2866-2877. DOI: $10.1109 / \mathrm{tmtt} .2017 .2675418$ 


\section{Аналіз розподілених двошарових ком- понентів у тришаровій планарній стру- ктурі}

\author{
Рассохіна Ю. В., Крижановсъкий В. Г.
}

Удосконалено та побудовано алгоритми для аналізу двошарових розподілених неоднорідностей у вигляді індуктивного відрізка мікросмужкової лінії передачі та Н-подібного щілинного резонатору із поперечним розташуванням гантелей у її заземлюючій площині методом поперечного резонансу. Згідно з методом, елементи матриці розсіювання на симетричній неоднорідності розраховуються з рішень двох крайових задач для резонатора з граничними умовами у вигляді електричної і магнітної стінки на поздовжніх границях резонатора щодо його розміру або резонансної частоти. Даний метод враховує взаємодію компонентів, що складають неоднорідність, оскільки базується на розв'язанні крайових задач для мікросмужкового резонатору, що містить в собі розподілену двошаророву неоднорідність цілком. Алгебраізація крайових задач виконується за допомогою базисних функцій хвилевідного типу, за якими розкладається поле на апертурі щілинного резонатора складної форми, i векторних потенщіалів (електричного і магнітного) для щільності струму в неоднорідній смужковій лінії. Для опису щільості струмів в смужковому резонаторі використовується тригонометричний базис, на основі якого будуються двовимірні власні функції векторних потенціалів для щільності струму. Результати чисельних розрахунків показали, що внесок електричного векторного потенціалу для щільності струму в значення резонансної частоти в числовому виразі складає близько $2 \%$ щодо середньої частоти діапазону. Тому для оптимізації часу, що витрачається на розрахунок однієї частотної точки, для опису щільності струму в смужковій лінії достатньо використовувати тільки магнітний векторний потенціал. Крім того, для істотного скорочення часу, що витрачається на розрахунок елементів матриці розсіювання для однієї частотної точки, використовується апроксимація кривих спектра власних частот резонатора раціональної функції у вигляді зворотного полінома порядку $\mathrm{m}$. За результатами аналізу розглянута неоднорідність $є$ багатофункціональним приладом, що має характеристики розсіювання, що містять одночасно смуги пропускання та запирання сигналу. При цьому неоднорідність забезпечує широкосмугове (до 40 \%) запирання із двочастотною характеристикою резонансного відбиття сигналу, а також формує або один широкосмуговий (до $10 \%$ ) смуго-пропускний фільтр, або два вузькосмугових (близько $3 \%$ ) смуго-пропускних фільтри.

Ключові слова: мікросмужкова лінія; індуктивний відрізок; Н-подібний щілинний резонатор; спектр власних частот; характеристики розсіювання

\section{Анализ распределенных двухслойных компонентов в трехслойной планарной структуре}

\author{
Рассохина Ю. В., Крыжановский В. Г.
}

Усовершенствованы и построены алгоритмы для анализа двухслойных распределенных неоднородностей в виде индуктивного отрезка в микрополосковой линии передачи и Н-образного щелевого резонатора с поперечным расположением "гантелей" в ее заземляющей плоскости методом поперечного резонанса. Согласно методу, элементы матрицы рассеяния на симметричной неоднородности рассчитываются из решений двух краевых задач для резонатора с граничными условиями в виде электрической и магнитной стенки на продольных границах резонатора относительно его размера или резонансной частоты. Данный метод учитывает взаимодействие компонентов, составляющих неоднородность, поскольку базируется на решении краевых задач для микрополоскового резонатора, включающего в себя распределенную двухслойную неоднородность целиком. Алгебраизация краевых задач выполняется с помощью базисных функций волноводного типа, по которым раскладывается поле на апертуре щелевого резонатора сложной формы, и векторных потенциалов (электрического и магнитного) для плотности тока в неоднородной полосковой линии. Для описания плотности токов в полосковом резонаторе используется тригонометрический базис, на основе которого строятся двумерные собственные функции векторных потенциалов для плотности тока. Результаты численных расчетов показали, что вклад электрического векторного потенциала для плотности тока в значение резонансной частоты в числовом выражении составляет около $2 \%$ относительно средней частоты диапазона. Поэтому для оптимизации времени, затрачиваемого на расчет одной частотной точки, для описания плотности тока в полосковой линии достаточно использовать только магнитный векторный потенциал. Кроме того, для существенного сокращения времени, затрачиваемого на расчет элементов матрицы рассеяния на одной частоте, используется аппроксимация кривых спектра собственных частот резонатора рациональной функцией в виде обратного полинома порядка $\mathrm{m}$. По результатам анализа, рассмотренная неоднородность является многофункциональным устройством и имеет характеристики рассеяния, которые содержат одновременно полосы пропускания и запирания сигнала. При этом неоднородность обеспечивает широкополосное (до 40 \%) запирание с двухчастотной характеристикой резонансного отражения, а также формирует либо один широкополосный (до 10\%) полосно-пропускающий фильтр, либо два узкополосных полосно-пропускающих фильтра (порядка 3\%).

Ключевые слова: микрополосковая линия; индуктивный отрезок; Н-образный щелевой резонатор; спектр собственных частот; характеристики рассеяния 